\title{
Systemic Lidocaine for Perioperative Analgesia: A Literature Review
}

\author{
Fabrício Tavares Mendonça*, Mariana Campos Reis, Jordana Alvene Aguiar and Luíse Anibal Calvano \\ Base Hospital of the Federal District, Brazil
}

Submission: November 17, 2015; Published: December 9, 2015

*Corresponding author: Fabrício Tavares Mendonça, Center of Teaching and Training of Brasilian Society of Aneshesiology, Base Hospital of the Federal District, SMHS101 -Special Area, Asa Sul, 70335-900, Tel: +556133151588; Email: fabricio.tavares@me.com

\begin{abstract}
Introduction and Background: Intravenous lidocaine has been increansingly used as pain treatment in anesthesiology. The aim of this study was to review the scientific literature on the use of lidocaine for perioperative analgesia, a recent technique and still under study to demonstrate its clinical implications.

Methodology: Data were derived from MD Consult e Clinical Key (1998-2014). A total of 32 articles were selected.

Results and Discussion: Lidocaine acts by changing the excitatory nerve impulse driving; decreasing visceral pain, central sensitization of pain and the immune response. Intravenous lidocaine with good clinical results were used in the dose of preoperative bolus 1,5 a 2 mg.kg-1 followed by continuous infusion 1,5 a 3 mg.kg-1.h-1. Most of clinical trials were in patients undergoing abdominal surgery. It is wellestablished analgesic, anti-inflammatory and anti-hyperalgesic properties of this local anesthetic; other of its beneficial effects were reduce consumption of volatile anesthetic and opioids, and fasten return of bowel function.
\end{abstract}

Conclusion: Systemic lidocaine was able to promote great analgesia in surgical procedures. It is a low cost and very convenient alternative on perioperative pain treatment. More clinical controlled studies in different surgical intervention may yield more information about this analgesic approach.

Keywords: Local anesthetics; Pain; Perioperative; Intravenous; Lidocaine

\section{Introduction}

Pain is a very common phenomenon on postoperative period and it is oftenly neglected. Pain control is essential for surgical patient assistance, as long as persistence of painful stimuli increase the incidence of complications. Acute pain is related to nociceptive stimuli produced by tissue damage, which results in a group of sensitive, cognitive and emotional experiences, generating autonomic and behavior responses. Acute and persistent painful stimuli may change nervous system's plasticity leading to its cronification $[1,2]$.

The goal of pain treatment is blocking the generation, transmission, perception end sensation of nociceptive stimuli in different levels of peripheral and central nervous system [1]. This reduces perioperative morbidity, favors surgical treatment result, reduces hospital expenses and decreases postoperative chronic pain risk $[3,4]$.
Nevertheless, many patients submitted to surgical procedures go through moderate to strong pain on postoperative period, indicating that despite of the development of new medications and implementation of different analgesic techniques, postoperative pain remains misdiagnosed and mistreated [5].

Opioid analgesics are commonly used in clinical practice for perioperative pain treatment. However, its use is related to many side effects, as respiratory depression, nausea, vomit, drowsiness, pruritus, urinary retention, constipation, hyperalgesia and immunologic function compromise [6]. Therefore, alternative techniques and medications have been used as substitute of opioid for analgesia, that is, where well fits the systemic intravenous infusion of lidocaine, local anesthetic widely used on anesthesiology practice [6-8].

Studies showed that the intraoperative use of lidocaine considerably diminished postoperative pain, but when administered only on postoperative period it did not have 
analgesic effective results. The mechanisms of analgesia of this local anesthetic on surgical trauma include neuronal transmission blockage at the place of injury, reducing neurogenic response and systemic anti-inflammatory intrinsic activity. Lidocaine's analgesic property can persist even after the decreasing of its plasmatic levels, which corroborates the nervous conduction blockage theory [6,8-13].

Intraoperatively, aside from analgesia, lidocaine also promotes reduction of inhaled anesthetics and opioid consumption, earlier return of bowel function, diminished production of interleukines and reduction airway reactivity [9]. This local anesthetic has important anti-inflammatory properties: reduces cytokine release in vitro and in vivo by inhibiting neutrophile activation $[10,11]$.

There are few studies with systemic lidocaine use during the perioperative period and intravenous injection of local anesthetic is still surprising for many medical professionals, what aroused interest in the subject chosen for this review.

\section{Methodology}

We performed a critical review of literature from March 2011 to March 2014. Articles found on the data base MD Consult e Clinical Key and published from 1998-2014 were considered. We used free text and MeSH terms - local anesthetics, pain, perioperative, intravenou, and lidocaine - for articles in Portuguese and English language. We recruited additional studies from bibliographies of retrieved trials and previous reviews. We excluded data from abstracts, case reports and letters. Of the 463 articles screened, 431 were excluded. A total of 32 articles were selected, and these were review of the pharmacological aspects of lidocaine and clinical trials using this local anesthetic for intravenous continuous infusion perioperatively.

\section{Results and Discussion}

\section{Pharmacological Properties}

Lidocaine has been used for several indications such as regional anesthesia, antiarrythmic, on peripheral and central pain treatment, and as adjuvant on postoperative acute pain treatment including opioid refractory cases [8]. Recent researches have shown its mechanism in a more detailed way, emphasizing its multimodal action.

Lidocaine or 2-(Diethylamino)-N-(2,6-dimethylphenyl)acetamide is a weak base, with a pKa of 7,9. In general, local anesthetics with a pKa that approximates physiologic $\mathrm{pH}$ have a higher concentration of non-ionized base resulting in a faster onset. Lidocaine itself has a great amount of lipid soluble and non-ionized local anesthetic on plasma, therefore it has the property of easily penetrating the neural sheath and axonal membrane $[8,13]$.

Lidocaine and its metabolites monoethylglycinexylidide (MEGX), glycinexylidide, and N-ethylglycine, interacts with peripheral and central voltage-gated sodium channel on intracellular face of membrane blocking the start and conduction of neural impulses potencial [8].

When intravenously administered, this local anesthetic is first distributed to highly perfused organs such as brain, heart, lung, liver and kidney, followed by less perfused tissues like skin, skeletal muscles, fat and peripheral organs. Its volume of distribution is great, as $60 \%$ of its molecules are bind to plasma protein [12].

Close to $40 \%$ of systemic lidocaine is extracted at the first stage of the process at the lungs, highly reducing the intoxication probability after accidental intravascular injection [12]. Its elimination half-life is of 1,5 to $2 \mathrm{~h}$ and about $90 \%$ of the drug is metabolized by the liver, at the microsomal enzyme system (cytochrome P450). Its degradation pathway is mainly the conversion to monoethylglycinexylidide (MEGX) by oxidative $\mathrm{N}$-de-ethylation followed by hydrolysis to 2,6-xylidine. Those metabolites have active properties and have been related to toxicity cases of systemic local anesthetic after repeated bolus and continuous infusion. The lidocaine excretion occurs in the kidneys through an early renal elimination, from 8 to 17 minutes, and a late phase elimination of 87 to 108 minutes [12].

\section{Mechanism of Action}

Lidocaine's intravenous administration has peripheral and central action, and involves several mechanisms: sodium channel and NMDA (N-methyl-D-aspartate) receptors block, glycinergic action and substance $P$ decrease. In low concentration, it inhibits primary afferent fibers abnormal activity, mainly at C fibers; causes sympathetic block, vasodilation and breaks the sequence of action that perpetuates the painful stimulus. In therapeutic plasma concentrations (1,5 a $5 \mu$ g.mL-1), it diminishes the hiperexcitability without affecting nerve conduction; promotes reduction of medular sensitivity and post-synaptic despolarization NMDA and neurocinine mediated; also reduces medullary neuron activity $[13,14]$.

Systemic lidocaine has antinociceptive effects in which glycinergic mechanisms might be involved. Synaptic levels of glycine, an important inhibitory neurotransmitter, is regulated by glycine transporters (GlyT1 and GlyT2). In a study that analysed GlyT1's function in rats astrocytes and frogs oocytes, the local anesthetic lidocaine itself, reduced glycine uptake only at toxic concentrations. However, the metabolites MEGX, glycinexylidide, and N-ethylglycine significantly reduced glycine uptake at a clinically relevant concentration increasing extracellular glycine levels. This increasing of the extracellular level of glycine at the synaptic cleft via blockade of GlyT1, inhibits the pathologically increased conduction of excitatory signs in glutamate and NMDA receptors responsible for the painful stimulus, assuring antinociceptive effect [14].

Besides of acting at voltage-gated sodium channels, studies showed that lidocaine yet has effects over G protein-gated, NMDA and calcium-activated potassium channels receptors, through 
what it alters the excitatory impulse conduction over A-delta and $\mathrm{C}$ fibers, modifying also visceral pain sensitivity, central sensitization and immunological response resulting from pain stimuli $[2,15,16]$.

In other hand, this local anesthetic seems to indirectly block NMDA receptors through proteinkinase Cinhibition, with impact over postoperative hiperalgesia and opioids tolerance [17].

When lidocaine is used systemicaly, there is an increasing of acetylcholine levels at the liquor, exacerbating pain sensitivity inhibition via descending inhibitory pain pathways, with consequent analgesia. Related to that, is likely that lidocaine's connection with M3 muscarinic, glycine receptors inhibition and endogenous opioid releasing corroborates to its analgesic final effect.

Reduction of inflammatory response to ischemia and diminution of endothelial cytokine-induced tissue damage through adenosine triphosphate release and potassium channel is something that also happens. It is wondered that systemic lidocaine may reduce myocardial ischemia, vasoconstriction and trombose mediator thromboxane $\mathrm{A} 2$ production by directly interacting with the endothelial membrane $[8,13]$.

Lidocaine interferes in a few inflammatory processes like oxygen free radicals production, lisosomic neutrofile sensitization and degranulation, and cytokine releasing at macrophages and glia cells. It also reduces cytokine induced cellular damage through mitochondrial potassium channels adenosine triphosphate sensitive $[18,19]$.

In summary, the mechanism of action of this local anesthetic is capable of promoting clinically relevant relief of spontaneous pain, dysesthesia, hiperalgesia and mechanicallodynia through various pathways $[13,20]$.

\section{Toxicity}

As systemic lidocaine's circulation level increases, the signs and symptoms of its effects over central nervous and cardiovascular systems are manifested.

Lidocaine's plasma concentrations below $5 \mu \mathrm{g} \cdot \mathrm{mL}^{-1}$ causes analgesia and inhibition of cortical motoneurons, justifying its anticonvulsive action [20]. In higher seric levels, from 5 to 10 $\mu \mathrm{g} . \mathrm{mL}^{-1}$, there is perioral paresthesia, metallic taste, dizziness, diplopia, tinnitus, drowsiness, confusion, agitation, muscle twitching and seizure. The last one happens with doses between 10 and $15 \mu \mathrm{g} \cdot \mathrm{mL}^{-1}[13]$.

Many times, seizure is the first sign of severe local anesthetic toxicity. It occurs because of inhibition of the inhibitory neurons through GABA (gamma-aminobutyric acid) receptors stimulation at central amygdala. The seizure usually happens when lidocaine's plasmatic concentration is over $8 \mu \mathrm{g} . \mathrm{mL}^{-1}$, although it can arise in lower concentrations in hipercarbia situations [15]. Yet, cardiovascular toxicity goes with depression of myocardial automatism in lidocaine doses higher than 25 $\mu \mathrm{g} . \mathrm{mL}^{-1}$. It manifests as bradycardia, prolonged PR interval and wide QRS complex, conduction block, progressive hypotension and ventricular arrhythmias. Severe cardiac toxicity demands almost three times the seric concentration that causes seizures.

The treatment of the toxicity must include clinical support with oxygenation, hydrating and use of vasopressors, inotropic, antiarrhythmic and anticonvulsivants according to clinical needs [21]. Implementing lipid therapy is indicated to prevent cardiovascular collapse based on clinical severity and rate of progression of symptoms, since only a fraction of patients will progress to severe toxicity to local anesthetics [22].

\section{Clinical Studies}

Systemic lidocaine used in continuous infusion on perioperative period has analgesic, antihiperalgesic and antiinflammatory properties, which makes it capable of reducing intra and postoperative drugs consumption and patients hospital stay [16,19]. Its effects are mostly pronounced with intraoperative infusion followed by postoperative infusion of intravenous lidocaine for days and even weeks, that is long time infusion and over the drug's plasmatic half-life applicability. This indicates that lidocaine's action is not limited to voltage-gated sodium channels but it is extended to other goals, and suggests prevention of hypersensitivity at the central and peripheral nervous system regularly started and kept by painful stimuli $[6,18]$.

Lidocaine's intravenous most appropriate dose for treating post operative pain in a more efficient way is not yet defined. Some authors have shown that low doses like in between 1,5 e $3 \mathrm{mg} \cdot \mathrm{kg}^{-1} \cdot \mathrm{h}^{-1}$ (plasmatic levels lower than $5 \mu \mathrm{g} \cdot \mathrm{mL}^{-1}$ ) reduce pain after surgical procedures with lower incidence of side effects and without influence at nerve conduction [15,16,18,23].

Grigoras and colleagues, made a prospective, double blinded, controlled clinical trial in 36 patients Asa I e II, submitted to total mastectomy with or without complete axillary dissection. Of those, 17 received intravenous infusion of lidocaine 1,5 $\mathrm{mg} \cdot \mathrm{kg}^{-1}$ in $10 \mathrm{~min}$ immediately after orotracheal intubation, followed by $1,5 \mathrm{mg} \cdot \mathrm{kg}-1 . \mathrm{h}^{-1}$ stopped $60 \mathrm{~min}$ after skin closure. The 19 other patients received saline solution under the same scheme. All patients were evaluated for acute pain and postoperative pain persisting after three months, besides the extension of secondary hiperalgesia area. As a result, there was that morfine consumption was alike on both groups during the first $4 \mathrm{~h}$ postoperative; plasmatic lidocaine levels were in the adequate average considering the drug's toxicity; lower incidence of postoperative persistent pain and smaller extension of hiperalgesia area at the surgical incision at the systemic lidocaine continuous infusion group [24]. In other words, this study brought to evidence the analgesic and antihiperalgesic properties of the systemic use of lidocaine via venous infusion perioperatively, offering better postoperative pain control, what may also be a way of preventing pain cronification [2]. 
Koppert [25] and collaborators demonstrated that patients whom received lidocaine via venous infusion in low doses intra and postoperatively (bolus of $1,5 \mathrm{mg} \cdot \mathrm{kg}^{-1}$ for about 30 minutes before surgical incision, followed by continuous infusion of 1,5 mg.kg-1 ${ }^{-1} h^{-1}$ until 60 minutes after end of surgery) felt less pain at mobilization and needed less amount of morfine at the first $72 \mathrm{~h}$ after abdominal surgery compared to patients that didn't receive lidocaine. As this effect of reducing opioid needs was more evident at the third day of postoperative period, lidocaine may have a truly preventive analgesic activity avoiding pain sensibilization and its consequent central induced hiperalgesia in a clinically relevant way [17].

In a clinical trial made by Kaba and colleagues, lidocaine was used in patients undergoing laparoscopic colectomy administered as bolus of $2 \mathrm{mg} \cdot \mathrm{kg}-1$ pre-incisional and kept as continuous infusion of $3 \mathrm{mg} . \mathrm{kg}-1 . \mathrm{h}-1$ till the end of the procedure promoting significant relief of postoperative pain and fatigue, faster return of bowel function, lower volatile anesthetic and opioid consumption, reduction of interleukine production (IL1AR, IL-6 e IL-8) and of the hospitalization time [16].

Herroeder and collaborators achieved similar results in a group of 60 patients submitted to colorectal surgery that refused or had contraindications to epidural catheter. It was infused intravenously lidocaine bolus of $1,5 \mathrm{mg} \cdot \mathrm{kg}^{-1}$ before induction of anesthesia, followed by continuous infusion of 2 mg.min-1 till 4 hours after surgery. Lidocaine significantly decreased return of bowel function period and reduced time of hospital stay in one day. Besides of that, it was found important attenuation of increasing of inflammatory markers suggesting an anti-inflammatory activity and a potential modulating effect over inflammatory response to surgical stress. There was no difference in pain evaluation criteria. Nevertheless, systemic use of lidocaine may be a very convenient and low cost alternative to get analgesia and satisfactory anesthetic outcomes in patients that cannot go through epidural anesthesia[26].

Marret and colleagues performed a metanalysis that selected 8 randomized, double-blinded clinical studies that evaluated a total of 320 patients undergone exclusively to abdominal surgeries. Of those patients, 161 received intravenous infusion of lidocaine and 159 received placebo. In 7 of the studies lidocaine was administered in bolus of 1,5 a 2 mg. $\mathrm{kg}^{-1}$ initiated before surgical incision, followed by continuous infusion at the same dose till the end of surgery or $24 \mathrm{~h}$ postoperative. In the 8 studies evaluated, the result of systemic lidocaine's use was reduction of postoperative paralytic ileus duration, pain, nausea and vomit and time of hospital stay [27].

Saadawy and collaborators made a double-blinded study in 120 patients submitted to laparoscopic cholecystectomy using the lidocaine dose of bolus of $2 \mathrm{mg}^{\mathrm{kg}} \mathrm{kg}^{-1}$ followed by continuous infusion of $2 \mathrm{mg} \cdot \mathrm{kg}^{-1} \cdot \mathrm{h}^{-1}$. There was lower need of morfine use at the second postoperative hour. The lidocaine group had lower scores of abdominal pain at rest and during coughing episodes, with 2,6 e $12 \mathrm{~h}$ postoperative, and faster recovery of bowel function. At the end of lidocaine's infusion it's plasmatic levels were of $2,6 \mu \mathrm{g} \cdot \mathrm{mL}^{-1}$ [28].

Yardeni and colleagues examined 65 patients undergoing hysterectomy under general anesthesia. The group that used lidocaine had $2 \mathrm{mg} . \mathrm{kg}^{-1}$ bolus at anesthetic induction followed by $1,5 \mathrm{mg} \cdot \mathrm{kg}^{-1} \cdot \mathrm{h}^{-1}$ in continuous infusion till end of surgery. This group presented lower scores of pain at rest and during coughing episodes at the first $8 \mathrm{~h}$ postoperative, and attenuation of immunologic response due to the lower production of cytokines pro and anti-inflammatory (IL-6 e IL-1ra respectively). This indicates that perioperatively use of systemic lidocaine improves acute pain control in immediate postoperative period and reduces surgical stress-induced immune response [29].

Wongyingsinn and collaborators evaluated 60 patients undergoing colorectal laparoscopic surgery in which it was used systemic lidocaine $1,5 \mathrm{mg}^{\mathrm{kg}}{ }^{-1}$ infusion (maximum of $100 \mathrm{mg}$ ) in anesthetic induction, maintained as $2 \mathrm{mg} \cdot \mathrm{kg}^{-1} \cdot \mathrm{h}^{-1}$ infusion until the end of the surgical procedure and $1 \mathrm{mg} \cdot \mathrm{kg}^{-1} \cdot \mathrm{h}^{-1}$ at the first $48 \mathrm{~h}$ postoperative. The authors compared epidural thoracic analgesia with general anesthesia and observed that systemic lidocaine produced similar benefits to return of bowel function and analgesia's global quality on patients submitted to colonic resection. There was no statistical difference at the time of hospital stay between the evaluated groups [30].

Swenson and collaborators studied 45 patients undergone to colon resection open surgery and compared epidural thoracic analgesia using bupivacaine $0,125 \%$ and hidromorfone $6 \mathrm{mcg} \cdot \mathrm{mL}-110 \mathrm{~mL} / \mathrm{h}$ for $1 \mathrm{~h}$ until the end of surgery, and general anesthesia with lidocaine bolus at induction with approximately $1,5 \mathrm{mg} \cdot \mathrm{kg}^{-1}$ and maintenance according to the scheme: 1 mg.min- 1 in $<70 \mathrm{~kg}$ patients and $2 \mathrm{mg}$.min- 1 in $\geq 70$ kg patients. The authors didn't notice any difference between the groups related to return of bowel function, time of hospital stay and postoperative pain control, suggesting once more that intravenous infusion of lidocaine may be an effective alternative to epidural therapy in patients that neuroaxial anesthesia is refused or contraindicated [31].

Kang and colleagues examined 48 patients submitted to gastrectomy under general anesthesia with intravenous lidocaine in bolus dose of $1,5 \mathrm{mg} \cdot \mathrm{kg}^{-1}$ at induction and same dose incontinuous infusion until the end of surgery. This technique significatively diminished the opioid postoperative consumption and time of hospital stay, although this study hasn't shown any improvement of pain levels and return of bowel function [32].

Most recently, Kyoung-Tae and collaborators evaluated the effect of intravenous lidocaine infusion on postoperative pain at lumbar microdiscectomy at a prospective, randomized, doubleblinded controlled clinical trial with 51 patients. The control group received lidocaine infusion pre and intraoperative in 1.5 
mg.kg-1 bolus followed by $2 \mathrm{mg} \cdot \mathrm{kg}^{-1} \cdot \mathrm{h}^{-1}$ infusion until the end of surgical procedure, and placebo infusion of saline solution. The lidocaine group had statistically relevant results with low pain scale scores and lower opioid consumption at first $48 \mathrm{~h}$ postoperatively and in the total amount, smaller frequency of patient controlled analgesia button push, shorter length of time of hospital stay and higher patient's satisfaction scores. That is, systemic lidocaine reduced the painful perception during microdiscectomy, consequently diminishing opioid consumption and postoperative pain intensity, which contributed to a shorter hospital stay [33] (Table 1).

Table 1: Effects of intravenous lidocaine infusion according to study time.

\begin{tabular}{|c|c|c|c|c|}
\hline Reference & Type of Study & Sample Group Profile & Lidocaine IV Infusion & Effects \\
\hline $\begin{array}{l}\text { Dirks et al. } \\
{[21]}\end{array}$ & $\begin{array}{l}\text { RCT } \\
\text { (Randomized } \\
\text { Controlled } \\
\text { Trial) }\end{array}$ & $\begin{array}{l}\text { The heat/capsaicin } \\
\text { sensitization model of } \\
\text { experimental pain in } 24 \\
\text { volunteers }\end{array}$ & $\begin{array}{l}\text { lidocaine } 2 \% \text { bolus } 2 \mathrm{mg} / \mathrm{kg} \text {, then } \\
\text { infusion } 3 \mathrm{mg} / \mathrm{kg} / \mathrm{h}\end{array}$ & $\begin{array}{l}\text { Systemic lidocaine showed a selective } \\
\text { effect on secondary hyperalgesia. }\end{array}$ \\
\hline $\begin{array}{l}\text { Koppert et al. } \\
{[22]}\end{array}$ & RCT & $\begin{array}{l}12 \text { volunteers capsaicin } \\
\text { injection sensitization } \\
\text { model }\end{array}$ & $\begin{array}{l}\text { lidocaine } 2 \% \text { bolus injection of } \\
2 \mathrm{mg} / \mathrm{kg} \text { in } 10 \text { min followed by } \\
\text { an intravenous infusion of } 2 \mathrm{mg} / \\
\mathrm{kg} / \mathrm{h} \text { for another } 50 \mathrm{~min}\end{array}$ & $\begin{array}{l}\text { Systemic lidocaine reduces pin- } \\
\text { prickhyperalgesia by a central mode of } \\
\text { action. }\end{array}$ \\
\hline $\begin{array}{l}\text { Koppert et al. } \\
{[17]}\end{array}$ & RCT & $\begin{array}{l}40 \text { patients undergoing } \\
\text { major abdominal surgery }\end{array}$ & $\begin{array}{l}\text { lidocaine } 2 \% \text { bolus } 1.5 \mathrm{mg} / \mathrm{kg} \text { in } \\
10 \mathrm{~min} \text { followed by } 1.5 \mathrm{mg} / \mathrm{kg} / \mathrm{h} \\
\text { (infusion started } 30 \mathrm{~min} \text { before } \\
\text { skin incision and was stopped } 1 \mathrm{~h} \\
\text { after the end of surgery) }\end{array}$ & $\begin{array}{l}\text { Patients who received lidocaine reported } \\
\text { less pain during movement and needed } \\
\text { less morphine during the first } 72 \mathrm{~h} \text { after } \\
\text { surgery. }\end{array}$ \\
\hline $\begin{array}{l}\text { Finnerup et al. } \\
{[15]}\end{array}$ & & $\begin{array}{l}24 \text { spinal cord injury } \\
\text { patients with neuropathic } \\
\text { pain }\end{array}$ & $\begin{array}{l}5 \mathrm{mg} / \mathrm{kg} \text { lidocaine } 2 \% \text { infused } \\
\text { over } 30 \mathrm{~min}\end{array}$ & $\begin{array}{l}\text { Lidocaine reduced neuropathic pain at } \\
\text { and below the level of injury irrespective } \\
\text { of the presence or absence of evoked pain. }\end{array}$ \\
\hline $\begin{array}{l}\text { Kuo et al. } \\
{[16]}\end{array}$ & RCT & $\begin{array}{l}60 \text { patients submitted to } \\
\text { colonic surgery }\end{array}$ & $\begin{array}{l}\text { IV and epidural: Lidocaine } 2 \% \\
\text { bolus } 2 \mathrm{mg} / \mathrm{kg} \text { followed by } 3 \mathrm{mg} / \\
\mathrm{kg} / \mathrm{h} \text { (infusion started } 30 \mathrm{~min} \\
\text { before surgery and maintained } \\
\text { throughout procedure) }\end{array}$ & $\begin{array}{l}\text { Thoracic epidural analgesia with } \\
\text { lidocaine had better pain relief, lower } \\
\text { opioid consumption, earlier return of } \\
\text { bowel function and lesser production of } \\
\text { cytokines than IV lidocaine during } 72 \mathrm{~h} \\
\text { after colonic surgery. }\end{array}$ \\
\hline $\begin{array}{l}\text { Wu et al. } \\
{[18]}\end{array}$ & RCT & $\begin{array}{l}100 \text { patients scheduled } \\
\text { for elective laparoscopic } \\
\text { cholecystectomy }\end{array}$ & $\begin{array}{l}\text { Lidocaine } 2 \% 3 \mathrm{mg} / \mathrm{kg} / \mathrm{h} \\
\text { (infusion started } 30 \mathrm{~min} \text { before } \\
\text { skin incision and maintained } \\
\text { throughout procedure) }\end{array}$ & $\begin{array}{l}\text { Additional effect on pain relief and a } \\
\text { synergistic effect on recovery of bowel } \\
\text { function when IM dextromethorphan } \\
\text { was combined with IV lidocaine after } \\
\text { laparoscopic cholecystectomy. }\end{array}$ \\
\hline $\begin{array}{l}\text { Kaba et al. } \\
\text { [19] }\end{array}$ & RCT & $\begin{array}{l}40 \text { patients scheduled } \\
\text { to undergo laparoscopic } \\
\text { colectomy }\end{array}$ & $\begin{array}{l}\text { Lidocaine } 2 \% \text { bolus injection } \\
\text { of } 1.5 \mathrm{mg} / \mathrm{kg} \text { at induction of } \\
\text { anesthesia, then infusion of } \\
2 \mathrm{mg} / \mathrm{kg} / \mathrm{h} \text { intraoperatively } \\
\text { and } 1.33 \mathrm{mg} / \mathrm{kg} / \mathrm{h} \text { for } 24 \mathrm{~h} \\
\text { postoperatively) }\end{array}$ & $\begin{array}{l}\text { Intravenous lidocaine improves } \\
\text { postoperative analgesia, fatigue, and } \\
\text { bowel function after laparoscopic } \\
\text { colectomy. These benefits are associated } \\
\text { with a significant reduction in hospital } \\
\text { stay. }\end{array}$ \\
\hline $\begin{array}{l}\text { Herroeder et } \\
\text { al. [20] }\end{array}$ & RCT & $\begin{array}{l}60 \text { patients undergoing } \\
\text { colorectal surgery, not } \\
\text { willing or unable to receive } \\
\text { an epidural catheter }\end{array}$ & $\begin{array}{l}\text { Lidocaine } 2 \% \text { bolus } 1.5 \mathrm{mg} / \mathrm{kg} \\
\text { before induction of anesthesia } \\
\text { followed by a continuous infusion } \\
\text { of } 2 \mathrm{mg} / \mathrm{min} \text { until } 4 \text { hours } \\
\text { postoperatively }\end{array}$ & $\begin{array}{l}\text { Lidocaine significantly accelerated return } \\
\text { of bowel function and shortened length of } \\
\text { hospital stay by one day. } \\
\text { Elevated plasma levels of IL-6, IL-8, } \\
\text { C3a, IL-1ra, CD11b, L- and P-selectin, } \\
\text { and platelet-leukocyte aggregates were } \\
\text { significantly attenuated by systemic } \\
\text { lidocaine. }\end{array}$ \\
\hline $\begin{array}{l}\text { Marret et al. } \\
{[26]}\end{array}$ & Meta-analysis & $\begin{array}{l}8 \text { RCT comparing } \\
\text { continuous intravenous } \\
\text { lidocaine infusion during } \\
\text { and after abdominal } \\
\text { surgery with placebo (total } \\
\text { of } 320 \text { patients) }\end{array}$ & $\begin{array}{l}\text { In seven of the eight RCTs, a } \\
\text { lidocaine } 2 \% \text { bolus }(1 \bullet 5-2 \mathrm{mg} / \\
\mathrm{kg} \text { ) was given before surgical } \\
\text { incision followed by a continuous } \\
\text { infusion until the end of operation } \\
\text { or } 24 \text { hour after it }\end{array}$ & $\begin{array}{l}\text { Intravenous lidocaine administration } \\
\text { decreased the duration of ileus, length of } \\
\text { hospital stay, postoperative pain intensity } \\
\text { at } 24 \mathrm{~h} \text { after operation and vomiting. }\end{array}$ \\
\hline
\end{tabular}




\begin{tabular}{|c|c|c|c|c|}
\hline $\begin{array}{l}\text { Yardeni et al. } \\
\text { [29] }\end{array}$ & RCT & $\begin{array}{l}65 \text { female patients } \\
\text { scheduled for } \\
\text { transabdominal } \\
\text { hysterectomy }\end{array}$ & $\begin{array}{l}\text { lidocaine } 2 \% \text { IV (bolus injection } \\
\text { of } 2 \mathrm{mg} / \mathrm{kg} \text { lidocaine through the } \\
\text { numbered syringe followed by a } \\
\text { continuous IV infusion of } 1.5 \mathrm{mg} / \\
\mathrm{kg} / \mathrm{h} \text { until the end of surgery) } \\
+ \text { patient-controlled epidural } \\
\text { analgesia }\end{array}$ & $\begin{array}{l}\text { There was significantly less ex-vivo } \\
\text { production of IL-1ra and IL- } 6 \text { in the group } \\
\text { lidocaine + patient-controlled epidural } \\
\text { analgesia. }\end{array}$ \\
\hline $\begin{array}{l}\text { Saadawy et al. } \\
\text { [28] }\end{array}$ & RCT & $\begin{array}{l}120 \text { patients undergoing } \\
\text { a laparoscopic } \\
\text { cholecystectomy }\end{array}$ & $\begin{array}{l}\text { lidocaine } 2 \% 2 \mathrm{mg} / \mathrm{kg} \text { bolus } \\
15 \mathrm{~min} \text { before induction of } \\
\text { anesthesia followed by } 2 \mathrm{mg} / \\
\mathrm{kg} / \mathrm{h} \text { infusion through the end of } \\
\text { surgery }\end{array}$ & $\begin{array}{l}\text { Lidocaine reduced anesthetic } \\
\text { requirements, pain scores and morphine } \\
\text { consumption relative to the control group. } \\
\text { Lidocaine was associated with earlier } \\
\text { return of bowel function. }\end{array}$ \\
\hline $\begin{array}{l}\text { Wongyingsinn } \\
\text { et al. } \\
{[30]}\end{array}$ & RCT & $\begin{array}{l}60 \text { patients scheduled } \\
\text { for elective laparoscopic } \\
\text { colorectal surgery }\end{array}$ & $\begin{array}{l}\text { Lidocaine } 2 \% 1 \mathrm{mg} / \mathrm{kg} / \mathrm{h}+ \\
\text { patient-controlled analgesia } \\
\text { morphine for the first } 48 \text { hours } \\
\text { after surgery }\end{array}$ & $\begin{array}{l}\text { Thoracic epidural analgesia provided } \\
\text { better analgesia in patients undergoing } \\
\text { rectal surgery. Time out of bed, dietary } \\
\text { intake and hospital stay were similar. }\end{array}$ \\
\hline $\begin{array}{l}\text { Swenson et al. } \\
\text { [31] }\end{array}$ & RCT & $\begin{array}{l}42 \text { patients undergoing } \\
\text { open colon surgery }\end{array}$ & $\begin{array}{l}\text { Lidocaine } 2 \%(1 \mathrm{mg} / \mathrm{min} \text { in } \\
\text { patients }<70 \mathrm{~kg}, 2 \mathrm{mg} / \mathrm{min} \text { in } \\
\text { patients }>\text { or }=70 \mathrm{~kg})\end{array}$ & $\begin{array}{l}\text { No differences were observed between } \\
\text { lidocaine IV and epidural analgesia } \\
\text { groups in terms of return of bowel } \\
\text { function, duration of hospital stay, and } \\
\text { postoperative pain control. }\end{array}$ \\
\hline $\begin{array}{l}\text { Grigoras et al. } \\
\text { [27] }\end{array}$ & RCT & $\begin{array}{l}36 \text { patients undergoing } \\
\text { surgery for breast cancer }\end{array}$ & $\begin{array}{l}\text { Lidocaine } 2 \% \text { IV bolus of } 1.5 \\
\mathrm{mg} / \mathrm{kg} \text { before induction of } \\
\text { general anesthesia, followed by } \\
\text { continuous infusion of } 1.5 \mathrm{mg} / \\
\mathrm{kg} / \mathrm{h} \text { stopped } 1 \text { hour after the } \\
\text { skin closure }\end{array}$ & $\begin{array}{l}\text { Intravenous perioperative lidocaine } \\
\text { decreases the incidence and severity } \\
\text { of persistent postsurgical pain after } \\
\text { breast cancer surgery. Prevention of the } \\
\text { induction of central hyperalgesia is a } \\
\text { potential mechanism. }\end{array}$ \\
\hline $\begin{array}{l}\text { Kang et al. } \\
{[32]}\end{array}$ & RCT & $\begin{array}{l}48 \text { men scheduled for } \\
\text { subtotal gastrectomy }\end{array}$ & $\begin{array}{l}\text { Lidocaine } 2 \% 1.5 \mathrm{mg} / \mathrm{kg} \text { bolus } 20 \\
\text { minutes before incision followed } \\
\text { by a continuous infusion of } 1.5 \\
\mathrm{mg} / \mathrm{kg} / \mathrm{h} \text { until the end of surgery }\end{array}$ & $\begin{array}{l}\text { Intraoperative IV low-dose lidocaine } \\
\text { infusion decreased opioid consumption } \\
\text { and hospital length of stay after } \\
\text { gastrectomy. No differences were noted } \\
\text { between the groups in pain intensity or } \\
\text { duration of ileus. }\end{array}$ \\
\hline $\begin{array}{l}\text { Kyoung-Tae } \\
\text { et al. } \\
\text { [33] }\end{array}$ & RCT & $\begin{array}{l}\text { Fifty-one patients } \\
\text { undergoing lumbar } \\
\text { microdiscectomy }\end{array}$ & $\begin{array}{l}\text { Lidocaine } 2 \% 1.5-\mathrm{mg} / \mathrm{kg} \text { bolus } \\
\text { followed by a } 2-\mathrm{mg} / \mathrm{kg} / \mathrm{h} \text { infusion } \\
\text { until the end of the surgical } \\
\text { procedure }\end{array}$ & \\
\hline
\end{tabular}

In general, this literature review analysis showed that in most of the clinical studies selected systemic lidocaine for perioperative analgesia was used in the dose of 1,5 a $2 \mathrm{mg} . \mathrm{kg}^{-1}$ in bolus at anesthetic induction followed by continuous infusion of 1,5 a $3 \mathrm{mg} \cdot \mathrm{kg}^{-1} \cdot \mathrm{h}^{-1}$ intraoperative until the end of the surgical procedure. It was seen that lidocaine, in this therapeutic form, produces clinically relevant analgesia intra and postoperatively, prevents chronic pain, reduces consumption of volatile anesthetics and opioid, significantly accelerates return of bowel function and, this way, reduces time of hospital stay. Yet, it came to evidence that lidocaine causes important attenuation of production of various inflammatory markers suggesting an antiinflammatory activity and potencial mechanism of modulation of surgical stress-induced inflammatory response. All these findings show that intravenous continuous infusion of lidocaine in the perioperative period may be a convenient and low cost alternative to achieve analgesia and satisfactory anesthetic outcomes in patients that cannot undergo epidural anesthesia.

\section{Conclusion}

In the past years, the use of systemic lidocaine as analgesic perioperative technique gained more visibility. This literature review verified that the dose of intravenous lidocaine with good clinical outcomes was bolus of 1,5 a $2 \mathrm{mg} \mathrm{kg}^{-1}$ in the anesthetic induction followed by continuous infusion of 1,5 a $3 \mathrm{mg} \cdot \mathrm{kg}^{-1} \cdot \mathrm{h}^{-1}$ intraoperative until the end of the surgical procedure.

It was concluded that the recent studies prove the efficiency of the use of this local anesthetic on the perioperative period because of its properties of acute pain relief and chronic pain 
prevention, besides of reducing the consumption of anesthetics and promoting early return of bowel function, accelerating hospital discharge.

This way, systemic lidocaine should be seen as one more option of analgesia on anesthesiologists antalgic therapy wide range of medication possibilities. Its administration is low cost compared to other medications, also more achievable and clinically safe in posologic well established limits, with specific indication and good alternative to promote efficient analgesia in patients that have any contraindication to neuroaxial anesthesia. The effort of elaborating more controlled clinical studies with the use of systemic lidocaine in different surgical intervention may bring more relevant information about this analgesic approach.

\section{References}

1. Pimenta CA, Santos EM, Chaves LD, Martins LM, Gutierrez BA (2001) Control of the postoperative pain. Rev Esc Enferm USP 35(2): 180-183.

2. Reuben SS (2007) Chronic Pain After Surgery: What Can We Do to Prevent It? Curr Pain Headache Rep 11(1): 5-13.

3. Kehlet H, Holte K (2001) Effect of postoperative analgesia on surgical outcome. Br J Anaesth 87(1): 62-72.

4. Kehlet H, Wilmore DW (2002) Multimodal strategies to improve surgical outcome. Am J Surg 183(6): 630-641.

5. Apfelbaum JL, Chen C, Mehta SS, Gan TJ (2003) Postoperative pain experience: results from a national survey suggest postoperative pain continues to be undermanaged. Anesth Analg 97(2): 534-540

6. Tanaka PP, Moss J (2008) The role of peripheral opiate antagonists in pain medicine and perioperative care. Rev Bras Anestesiol 58(5): 533547.

7. de Oliveira CM, Issy AM, Sakata RH (2010) Intraoperative intravenous lidocaine. Rev Bras Anestesiol 60(3): 325-333.

8. Lauretti GR (2008) Mechanisms of analgesia of intravenous lidocaine. Rev Bras Anestesiol 58(3): 280-286.

9. Beilin B, Shavit Y, Trabekin E, Mordashev B, Mayburd E, et al. (2003) The effects of postoperative pain management on immune response to surgery. Anesth Analg 97(3): 822-827.

10. Hollmann MW, Durieux ME (2000) Local anesthetics and the inflammatory response: a new therapeutic indication? Anesthesiology 93(3): 858-875.

11. de Klaver MJ, Buckingham MG, Rich GF (2003) Lidocaine attenuates cytokine-induced cell injury in endothelial and vascular smooth muscle cells. Anesth Analg 97(2): 465-470.

12. McLure HA, Rubin AP (2005) Review of local anaesthetic agents. Minerva Anestesiol 71(1): 59-74.

13. Becker DE, Reed KL (2006) Essentials of local anesthetic pharmacology. Anesth Prog 53(3): 98-110.

14. Werdehausen R, Kremer D, Brandenburger T, Schlösser L, Jadasz J, et al. (2012) Lidocaine Metabolites Inhibit Glycine Transporter 1: A Novel Mechanism for the Analgesic Action of Systemic Lidocaine? Anesthesiology 116(1): 147-158.

15. Kuo CP, Jao SW, Chen KM, Wong CS, Yeh CC, et al. (2006) Comparison of the effects of thoracic epidural analgesia and i.v infusion with lidocaine on cytokine response, postoperative pain and bowel function in patients undergoing colonic surgery. Br J Anaesth 97(5): 640-646.
16. Kaba A, Laurent SR, Detroz BJ, Sessler DI, Durieux ME, et al. (2007) Intravenous lidocaine infusion facilitates acute rehabilitation after laparoscopic colectomy. Anesthesiology 106(1): 11-18.

17. Dirks J, Fabricius P, Petersen KL, Rowbotham MC, Dahl JB, et al. (2000) The effect of systemic lidocaine on pain and secondary hyperalgesia associated with the heat/capsaicin sensitization model in healthy volunteers. Anesth Analg 91(4): 967-972.

18. Wu CT, Borel CO, Lee MS, Yu JC, Liou HS, et al. (2005) The interaction effect of perioperative cotreatment with dextromethorphan and intravenous lidocaine on pain relief and recovery of bowel function after laparoscopic cholecystectomy. Anesth Analg 100(2): 448-453.

19. Carvalho WA, Lemonica L (1998) Molecular and cellular mechanisms of inflammatory pain. Peripheral modulation and therapeutic advances. Rev Bras Anestesiol 48(2): 137-158.

20. Finnerup NB, Biering-Sørensen F, Johannesen IL, Terkelsen AJ, Juhl GI, et al. Intravenous lidocaine relieves spinal cord injury pain: a randomized controlled trial. Anesthesiology 102(5): 1023-1030.

21. Barash PG, Cullen BF, Stoelting RK, Cahakan MK, Stock MC (2009) Clinical Anesthesia, (6 $6^{\text {th }}$ edn), Lippincott Williams \& Wilkins, Philadelphia, USA. pp. 1512-1521.

22. Neal JM, Bernards CM, Butterworth JF, Di Gregorio G, Drasner K, et al. (2010) ASRA practice advisory on local anesthetic systemic toxicity. Reg Anesth Pain Med 35(2): 152-161.

23. Koppert W, Weigand M, Neumann F, Sittl R, Schuettler J, et al. (2004) Perioperative intravenous lidocaine has preventive effects on postoperative pain and morphine consumption after major abdominal surgery. Anesth Analg 98(4): 1050-1055.

24. Grigoras A, Lee P, Sattar F, Shorten G (2012) Perioperative intravenous lidocaine decreases the incidence of persistent pain after breast surgery. Clin J Pain 28(7): 567-572.

25. Koppert W, Ostermeier N, Sittl R, Weidner C, Schmelz M, et al. (2000) Low-dose lidocaine reduces secondary hyperalgesia by a central mode of action. Pain 85(1-2): 217-224.

26. Herroeder S, Pecher S, Schönherr ME, Kaulitz G, Hahnenkamp K, et al. (2007) Systemic lidocaine shortens length of hospital stay after colorectal surgery: a double-blinded, randomized, placebo-controlled trial. Ann Surg 246(2): 192-200.

27. Marret E, Rolin M, Beaussier M, Bonnet F (2008) Meta-analysis of intravenous lidocaine and postoperative recovery after abdominal surgery. Br J Surg 95(11): 1331-1338.

28. Saadawy IM, Kaki AM, Abd El Latif AA, Abd-Elmaksoud AM, Tolba OM (2010) Lidocaine vs. magnesium: effect on analgesia after a laparoscopic cholecystectomy. ActaAnaesthesiol Scand 54(5): 549556.

29. Yardeni IZ, Beilin B, Mayburd E, Levinson Y, Bessler H (2009) The effect of perioperative intravenous lidocaine on postoperative pain and immune function. Anesth Analg 109(5): 1464-1469.

30. Wongyingsinn M, Baldini G, Charlebois P, Liberman S, Stein B, et al. (2011) Intravenous lidocaine versus thoracic epidural analgesia: a randomized controlled trial in patients undergoing laparoscopic colorectal surgery using an enhanced recovery program. Reg Anesth Pain Med 36(3): 241-248.

31. Swenson BR, Gottschalk A, Wells LT, Rowlingson JC, Thompson PW, et al. (2010) Intravenous lidocaine is as effective as epidural bupivacaine in reducing ileus duration, hospital stay, and pain after open colon resection: a randomized clinical trial. Reg Anesth Pain Med 35(4): 370-376. 
32. Kang JG, Kim MH, Kim EH, Lee SH (2012) Intraoperative intravenous lidocaine reduces hospital length of stay following open gastrectomy for stomach cancer in men. J Clin Anesth 24(6): 465-470.
33. Kim KT, Cho DC, Sung JK, Kim YB, Kang H, et al. (2014) Intraoperative systemic infusion of lidocaine reduces postoperative pain after lumbar surgery: a double-blinded, randomized, placebo-controlled clinical trial. Spine J 14(8): 1559-1566. 